\title{
Enterprise Valuation Based on UFCF Discount Model Take Changyu A as an Example
}

\author{
Xiaohua Song ${ }^{1, a}$, Chen $\mathrm{Qi}^{2, \mathrm{~b}}$ \\ ${ }^{1,2}$ School of Economy and Management, North China Electric Power University, Beijing, China \\ aemail: sxh_bj@126.com, bemail: qichen19900820@sina.com
}

Keywords: Enterprise Value; UFCF model; Changyu A

\begin{abstract}
With the rapid development of China's capital market, the enterprise valuation becomes more and more important. In China, the discounted cash flow method is the most widely used method in the practice of enterprise valuation. This paper researched the related theories of unleveraged free cash flow discount model and assessed the enterprise value of Changyu using this model through historic data analysis, financial forecast, and valuation process. The results show that the UFCF model is effective and it still has some disadvantages in practice such as the difficult satisfaction of assumptions, the subjective forecasts and the result's sensitivity to discount rate and terminal value.
\end{abstract}

\section{Introduction}

After 1970s, the relationship between economic activities and financial activities became increasingly close and enterprise valuation became an integral part of corporate finance. Since 1980s, many developed countries' enterprises have entered a financial-oriented period when the enterprise value theory is the core of enterprise management theory. With the rapid development of China's capital market, restructuring, mergers and acquisitions events involving enterprise valuation are becoming more common and China is also starting to focus on enterprise valuation and its management. Enterprise valuation helps us examine enterprise's assets and environmental adaptability from a strategic point and provides a scientific, objective basis for enterprise's strategic decisions from a financial perspective. So it is meaningful to research enterprise valuation.

\section{Theoretical Analysis of UFCF Model}

UFCF Model. UFCF model is an absolute valuation method. We make the assumption that under normal operation, the maximum amount of cash that all investors can get from the company annually may not equal to the amount that the company allocates to the shareholders and creditors. So by discounting annual unlevered free cash flow, we can get the present value of the cash flow that all investors can get in the future, namely enterprise value.

$$
\mathrm{EV}=\sum_{\mathrm{t}=1}^{\mathrm{n}} \frac{\mathrm{UFCF}_{\mathrm{t}}}{\left(1+\text { WACC }^{\mathrm{t}}\right.}+\frac{\mathrm{TV}}{\left(1+\text { WACC }^{\mathrm{n}}\right.} .
$$

Where $U F C F_{t}$ is the unlevered free cash flow in year $\mathrm{t} ; \mathrm{n}$ is the number of detailed forecast periods; $W A C C$ is the weighted average cost of capital; $T V$ is the terminal value of unlevered free cash flow. Valuation process of UFCF model is shown in Figure 1.

Determination of Related Parameters. UFCF. Unlevered free cash flow (UFCF) means the cash flow that the company can allocate to all investors in the case of maintaining normal operations.

UFCF = EBIT - adjusted income tax + depreciation + amortization - increase of working capital + increase of long-term operating liabilities - capital expenditure

Estimation of Terminal Value. Gordon sustainable growth model and the terminal value multiple method are two ways can be used to predict the terminal value. If we assume UFCF grows at a stable rate $g$ after $n$ years, $E V$ is calculated as (2). If we suppose $M$ is $E B I T D A$ exit multiple of the last year of detailed forecast period and $E B I T D A_{n}$ is earnings before interest, taxes, depreciation and amortization 
of the last year of detailed forecast period. $E V$ is calculated as (3). In practice, evaluators usually take one as primary method with another as a helper method for mutual authentication.

$$
\begin{aligned}
& \mathrm{EV}=\sum_{t=1}^{\mathrm{n}} \frac{U F C F_{t}}{(1+W A C C)^{t}}+\frac{\mathrm{UFNF}_{\mathrm{n}} \times(1+g)}{(W A C C-g) \times(1+W A C C)^{n}}, \\
& \mathrm{EV}=\sum_{t=1}^{\mathrm{n}} \frac{U F C F_{t}}{(1+W A C C)^{t}}+\frac{\mathrm{EBITDA}_{\mathrm{n}} \times \mathrm{M}}{(1+W A C C)^{n}} .
\end{aligned}
$$

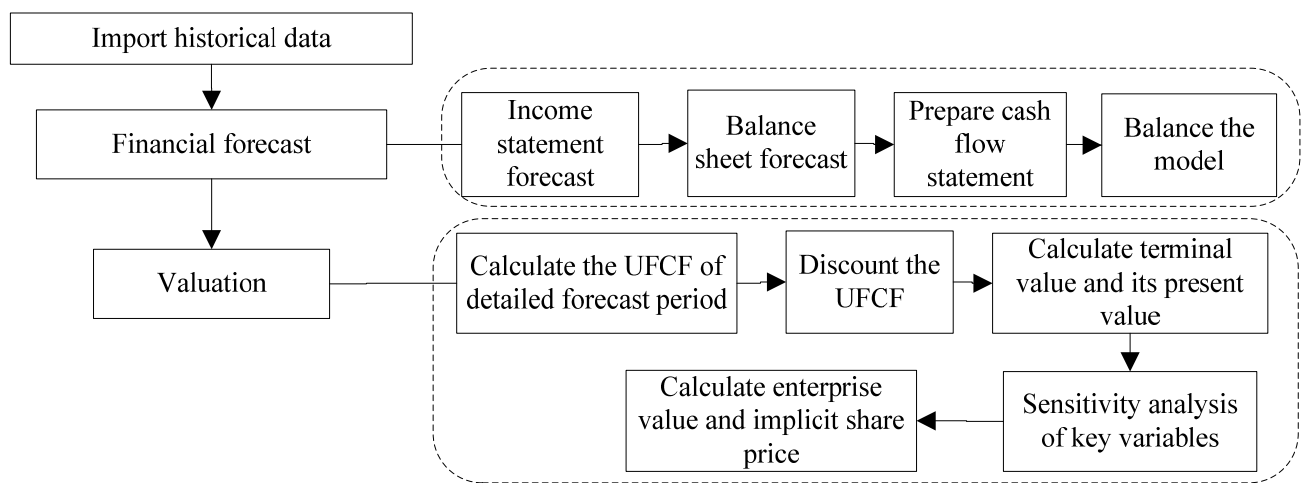

Fig. 1 UFCF model valuation flowchart

Estimation of WACC. WACC is the weighted average cost of capital of company's various sources of financing. Generally, when financing ways are only equity and debts, the formula of $W A C C$ is:

$$
W A C C=\frac{D}{D+E} \times k_{d} \times(1-t)+\frac{E}{D+E} \times k_{e} .
$$

Where, $D$ is the market value of the interest-bearing debts; $\mathrm{E}$ is the market value of equity; $K_{d}$ is the pre-tax cost of debt; $t$ is the statutory tax rate; $K_{e}$ is the cost of equity capital.

\section{Application Case of UFCF Model}

Basic Information of the Case. This paper takes Changyu A as an example. Changyu Group is the first manufacturer who industrialized the production of wine in China. Yantai Changyu Group Limited was founded in 1994 and Changyu B shares and A shares issued and listed successfully in 1997 and 2000 respectively. Now Changyu is the largest wine production and operation enterprise in China. Its productions' market share is more than $20 \%$ in China. In recent years, its sales and profit rank first in the Chinese wine industry.

The base date of assessment is June 30, 2012 and the detailed forecast period is from 2012 to 2021.

Table 1 Historical performance analysis of Changyu A

\begin{tabular}{lccc}
\hline \multicolumn{1}{c}{ year } & $\mathbf{2 0 0 9}$ & $\mathbf{2 0 1 0}$ & $\mathbf{2 0 1 1}$ \\
\hline current ratio & 1.8 & 2.14 & 2.28 \\
quick ratio & 1.28 & 1.45 & 1.42 \\
cash ratio & 1.18 & 1.32 & 1.25 \\
debt asset ratio & $40.82 \%$ & $33.21 \%$ & $29.41 \%$ \\
\hline inventory turnover ratio & 1.12 & 1.04 & 0.94 \\
accounts receivable turnover & 46.57 & 50.30 & 53.10 \\
current assets turnover & 1.24 & 1.26 & 1.39 \\
assets turnover ratio & 0.89 & 0.88 & 0.91 \\
\hline gross profit margin & $71.62 \%$ & $74.76 \%$ & $76.12 \%$ \\
net profit margin & $27.05 \%$ & $29.18 \%$ & $31.64 \%$ \\
ROE(net profit) & $35.78 \%$ & $36.39 \%$ & $37.03 \%$ \\
ROA(EBIT) & $31.84 \%$ & $34.01 \%$ & $38.34 \%$ \\
\hline
\end{tabular}


Historical Performance Analysis. Historical performance analysis is the basis of future UFCF forecast. The specific indicators are shown in Table 1. In solvency aspect, Changyu has greater assets liquidity and good short-term and long-term solvency. In operating capacity aspect, Changyu's accounts receivable turnover has a steady rising trend, which means it has a high accounts receivable realization speed. Lower inventory turnover rate is due to the nature of the wine industry. Company's large amount of cash and inventories leads to its lower assets turnover. The profitability indicators show a steady growth trend, mainly due to the high demand of the company's products.

Future Performance Prediction. Income Statement Forecast. Research report predicts the industry's production and sales will maintain a growth rate of $20 \%$ in the next three years. Changyu's historic average growth rate of operating income is $19.85 \%$, so we predict operating income growth rate equals to the industry level before 2015 , and then drops to $15 \%$ with the mature of industry. Costs and expenses are forecasted as percentages of operating income. The proportion of operating cost decreased year by year, and Changyu invests in fixed assets in recent years which will reduce the cost of raw materials, so we predict the proportion of operating cost is $22.5 \%$ in 2012, 21\% in 2013, 20\% in 2014 , and $19.5 \%$ in following years. The proportion of selling expenses will maintain the previous year's level of $26 \%$. As Changyu reports that they will strengthen the management, we predict the proportion of management expenses is 3.2\%, which is lower than the average of last three years. Following conservative principle, we forecast non-recurring or non-operating gains and losses are 0 .

Balance Sheet Forecast. Balance sheet is calculated from an intermediate calculation table. The proportion of fixed asset under acquisition and construction to operating income will be equal to the average of historical value $8.5 \%$ in next two years and $8 \%$ in the following years. Last three year's average value of the proportion of depreciation to initial amount of fix assets is $7.6 \%$, so we predict it's $8 \%$ in the future. Proportion of intangible assets under acquisition and construction to fixed assets under acquisition and construction and proportion of amortization to initial amount of intangible assets are $12 \%$ and $2 \%$ respectively which are the average of the three-year historical data. Corresponding proportions of account receivables, inventories, prepayments, other current assets, account payables, receipts in advance and other payables equal to average of the three-year historical value. According to the balance sheets of last three years, the short-term and long-term debts are 0 .

Cash Flow Statement Forecast. Taking into account the Changyu's trend of expansion and the average level of the industry, we assume the ratio of required cash to total operating income is $5 \%$.

Enterprise Valuation. Calculation of UFCF. Calulation process is shown in Table 2

Table 2 UFCF of detailed forecast period

\begin{tabular}{lrrrrrrrrrr} 
& \multicolumn{1}{c}{ Table 2 UFCF of detailed forecast period } & \multicolumn{1}{c}{ [million Yuan] } \\
\hline & $\mathbf{2 0 1 2 ( 6 )}$ & \multicolumn{1}{c}{$\mathbf{2 0 1 3}$} & $\mathbf{2 0 1 4}$ & $\mathbf{2 0 1 5}$ & $\mathbf{2 0 1 6}$ & $\mathbf{2 0 1 7}$ & $\mathbf{2 0 1 8}$ & $\mathbf{2 0 1 9}$ & $\mathbf{2 0 2 0}$ & $\mathbf{2 0 2 1}$ \\
\hline EBIT & $1,161.8$ & $2,977.6$ & $3,663.7$ & $4,455.6$ & $5,116.8$ & $5,877.8$ & $6,753.4$ & $7,760.8$ & $8,919.7$ & $9,112.2$ \\
(adjusted income tax) & $(288.8)$ & $(738.4)$ & $(908.6)$ & $(1,105.0)$ & $(1,269.0)$ & $(1,457.7)$ & $(1,674.8)$ & $(1,924.7)$ & $(2,212.1)$ & $(2,259.8)$ \\
EBIAT & 873.0 & $2,239.1$ & $2,755.1$ & $3,350.6$ & $3,847.9$ & $4,420.1$ & $5,078.6$ & $5,836.1$ & $6,707.6$ & $6,852.4$ \\
depreciation & 98.2 & 189.4 & 223.5 & 261.3 & 307.1 & 359.4 & 418.9 & 486.9 & 564.8 & 653.9 \\
amortization & $(3.3)$ & 6.4 & 7.8 & 9.3 & 11.1 & 13.2 & 15.6 & 18.3 & 21.4 & 25.0 \\
decrease of NOWC(increase) & 50.6 & 56.1 & 70.4 & 89.5 & 86.2 & 99.1 & 114.0 & 131.1 & 150.8 & 34.7 \\
increase of long term & 0.0 & 0.0 & 0.0 & 0.0 & 0.0 & 0.0 & 0.0 & 0.0 & 0.0 & 0.0 \\
$\begin{array}{l}\text { operating liabilities(decrease) } \\
\text { (fixed assets acquisition and }\end{array}$ & $(446.1)$ & $(615.8)$ & $(695.5)$ & $(834.6)$ & $(959.8)$ & $(1,103.8)$ & $(1,269.4)$ & $(1,459.8)$ & $(1,678.8)$ & $(1,729.1)$ \\
construction) & & & & & & & & & & \\
(intangible assets acquisition & $(59.7)$ & $(73.9)$ & $(83.5)$ & $(100.2)$ & $(115.2)$ & $(132.5)$ & $(152.3)$ & $(175.2)$ & $(201.5)$ & $(207.5)$ \\
and construction) & 512.8 & $1,801.3$ & $2,277.8$ & $2,775.9$ & $3,177.3$ & $3,655.5$ & $4,205.3$ & $4,837.5$ & $5,564.4$ & $5,629.4$ \\
UFCF & & & & & &
\end{tabular}

Determination of Discount Rate. Changyu almost has no debt, so $W A C C=K_{e}=R_{f}+\beta\left(R_{m}-R_{f}\right)$. $R f$ is the risk-free rate and we adopt the interest rate of treasury bonds $3.47 \%$. $R_{m}$ is the expected return rate of market portfolio. Plus average annual yield of U.S. stock market from 1926 to 2004 (10.4\%) to risk premium of emerging market (3\%), we get $R_{m}$ of China's A-share market $13.4 \%$. $\beta$ is 0.6 which is the 240 days' scroll value of daily return Beta on September 28, 2012.We get the WACC of 9.4\%.

Prediction of Terminal Value Related Parameters. By the year 2020, with the mature of the company, we predict the sustainable growth rate is 3\%. Under EBITDA exit multiples method, we let $M$ equal 5.19 which is U.S. beverage industry’s EV/ EBITDA value of the year 2003. 
Calculation of Enterprise Value. Except above prediction, we also do scenario analyses for operating income and operating cost based on the analysis of Changyu's operation, annual reports and related industry analysis reports. Related forecast data are displayed in Table 3.

Table 3 Scenario analysis of operating income and operating cost

\begin{tabular}{l|lllllllllll}
\hline \multicolumn{2}{l}{} & $\mathbf{2 0 1 2}$ & $\mathbf{2 0 1 3}$ & $\mathbf{2 0 1 4}$ & $\mathbf{2 0 1 5}$ & $\mathbf{2 0 1 6}$ & $\mathbf{2 0 1 7}$ & $\mathbf{2 0 1 8}$ & $\mathbf{2 0 1 9}$ & $\mathbf{2 0 2 0}$ & $\mathbf{2 0 2 1}$ \\
\hline $\begin{array}{l}\text { growth } \\
\text { rate of } \\
\text { operating } \\
\text { income }\end{array}$ & optimistic scenario & $9.6 \%$ & $22.8 \%$ & $22.8 \%$ & $22.8 \%$ & $17.1 \%$ & $17.1 \%$ & $17.1 \%$ & $17.1 \%$ & $17.1 \%$ & $3.4 \%$ \\
\hline $\begin{array}{l}\text { Operating } \\
\text { income/ }\end{array}$ & pessimistic scenario & $-5.0 \%$ & $14.5 \%$ & $14.5 \%$ & $14.5 \%$ & $10.5 \%$ & $10.5 \%$ & $10.5 \%$ & $10.5 \%$ & $10.5 \%$ & $2.0 \%$ \\
$\begin{array}{l}\text { operating } \\
\text { cost }\end{array}$ & basic scenario & $22.5 \%$ & $21.0 \%$ & $20.0 \%$ & $19.5 \%$ & $19.5 \%$ & $19.5 \%$ & $19.5 \%$ & $19.5 \%$ & $19.5 \%$ & $19.5 \%$ \\
\hline
\end{tabular}

Table 4 Results of Changyu's valuation

\begin{tabular}{ccc}
\hline \multicolumn{3}{c}{ stock price [Yuan/share] } \\
\hline calculation method of Terminal value & Gordon growth model & terminal multiple method \\
\hline optimistic scenario & $(109.39,144.62)$ & $(83.84,89.46)$ \\
basic scenario & $(83.32,109.21)$ & $(64.91,69.12)$ \\
pessimistic scenario & $(62.32,66.02)$ & $(45.72,48.47)$ \\
\hline
\end{tabular}

Combined with sensitivity analysis of $W A C C$ and $g$, the stock price of Changyu A on June 30, 2012 is shown in Table 4.The stock price of Changyu A was about 100 Yuan/share from 2010.9 to 2012.6. Because of economy weakness and pesticide event, Changyu's performance declined in the second half of 2012 and the stock price declined too. Until December 16, 2012, its stock price was 44.95 Yuan/share. This paper argues that China's capital market is not perfect, investors are lack of ration, and there are herd and overreaction phenomenon, as a result, Changyu $\mathrm{A}$ is undervalued.

\section{Summary}

From the case above, we can see that using UFCF model to valuate listed companies is effective. UFCF model is sound in theory, but it still has some disadvantages during the practical application. Firstly, the premises of the model are difficult to satisfied, such as the capital market is efficient. Secondly, many subjective assumptions need to be done in the financial forecast process and different modelers' assumptions may differ largely. Finally, the results of the valuation are sensitive to discount rate and terminal value. In this paper, we try to consider every factor that affects the enterprise value and get a value range at last. With the development of China's market economy and the continuous improvement of corporate governance level, the credibility and reliability of UFCF model will be higher and higher.

\section{References}

[1] Li Bin: Enterprise valuation of listed company based on FCF discount model: take kweichow moutai as an Example. Communication of Finance and Accounting, Vol. 27 (2012), p. 83-85.

[2] Wang Weidi: Research on investment value of listed wine companies. Zhe Jiang University, Zhe Jiang, (2011).

[3] Cheng Xun financial training company: Valuation Modeling (China Financial Publishing House, Beijing 2011).

[4] Chen Xi: Enterprise Valuation Based on EVA: Take Qingdao Haier as an Example. Communication of Finance and Accounting, Vol. 12 (2012), p 92-94.

[5] Yu Shubao: Comparison of DCF and EVA in Enterprise Evaluation Methods. Journal of Changchu University, Vol. 22 (2012), p. 261-264 